\title{
WCIELENIE W TEOLOGII MARCELEGO Z ANCYRY
}

Postać Marcelego z Ancyry jest związana głównie ze sporami ariańskimi ${ }^{1}$. Widzimy go najpierw na soborze w Nicei, a następnie jako jednego z najgorętszych przeciwników Ariusza, wspierającego Atanazego na synodzie w Tyrze (335). Tam wspólnie sprzeciwiają się rehabilitacji Ariusza. W tymże samym roku Marceli pisze dzieło polemiczne Przeciw Asteriuszowi ${ }^{2}$. W roku 336 zostaje usunięty z urzędu biskupiego przez cesarza Konstantyna. Wkrótce potem zostaje zaatakowany przez Euzebiusza z Cezarei w pismach Przeciw Marcelemu i $O$ teologii kościelnej ${ }^{3}$. To właśnie w tych dziełach przechowały się właściwie jedyne ocalałe fragmenty dzieł Marcelego ${ }^{4}$. Euzebiusz oskarża Marcelego przede wszystkim o sabelianizm. Po śmierci Konstantyna w 337 r., Marceli stara się powrócić na swoją stolicę biskupią, lecz nie udaje mu się na niej utrzymać z powodu wpływów na dworze cesarskim jego przeciwników. Wtedy to udaje się do Rzymu, aby szukać pomocy u papieża Juliusza I. Kilka miesięcy wcześniej przybył do Rzymu Atanazy. Marceli pisze do Juliusza, zachowany przez Epifaniusza, list, w którym stara się oczyścić z zarzutu sabelianizmu postawionego mu przez Euzebiusza z Cezarei i innych przeciwników ${ }^{5}$. W Rzymie, podczas synodu w 340 r. teologia Marcelego zostaje uznana za ortodoksyjną. Natomiast na Wschodzie Marceli nadal jest uznawany za wyznawcę heretyckich doktryn i kilkakrotnie ekskomunikowany przez tamtejsze synody. Nie może więc powrócić na swoją stolicę biskupią. Umiera ok. 375 roku. Ostatnio przypisuje mu się

${ }^{1}$ Bibliobrafię dotyczącą Marcelego zob.: Marceli z Ancyry, Fragmenty zachowanych pism (1-35). Wstęp i przekład J. Słomka, VoxP 17(1997) t. 32-33, 439-450.

2 Por. Liber contra Asterium (CPG 2800), fragmenty, ed. E. Klostermann, Leipzig 1906, 2. Aufl. G. Ch. Hansen, Berlin 1972, Eusebius Werke, IV, GCS 14, 185-215.

${ }^{3}$ Por. Contra Marcellum - De ecclesiastica theologia (CPG 3477, 3478), ed. E. Klostermann, Leipzig 1906, 2. Aufl. G. Ch. Hansen, Berlin 1972, Eusebius Werke, IV, GCS 14, 1-182, lub PG 24, 707-1046.

${ }^{4}$ Por. Die Fragmente Marcells, ed. E. Klostermann, Leipzig 1906, 2. Aufl. G. Ch. Hansen, Berlin 1972, w: Eusebius Werke, IV, GCS 14, 185-215.

${ }^{5}$ Por. Epistola ad Julium papam (CPG 2801), w: Epiphanius, Haeresis 72, 2, 3, ed. K. Holl: Epiphanius Werke, III, GCS 37, Leipzig 1933, 256-259, lub GCS 14, 214-215; PL 8, 915-919. 
traktat $O$ Kościele świętym ${ }^{6}$. Dzieło to jednak nie wnosi niczego istotnego do jego teologii i poświadcza, że i po latach pozostała ona w zasadzie niezmieniona.

Marceli jest uznawany za przedstawiciela teologii antiocheńskiej. Jak sam pisał, w całej swojej twórczości pragnął przede wszystkim wykazać, że jest jeden $\mathrm{Bóg}^{7}$. Ten radykalny monoteizm, mocno zakorzeniony w tradycji monarchianizmu antiocheńskiego, stanowi punkt wyjścia dla całego systemu teologicznego, jaki stworzył, i jest podstawą nieprzejednanej polemiki, jaką toczył z teologami orientacji Orygenesowej, oraz podstawą polemiki, jaką skierował przeciw niemu Euzebiusz z Cezarei, a po nim inni przedstawiciele tradycji aleksandryjskiej $^{8}$. W tradycji aleksandryjskiej bowiem mówiono o trzech hipostazach w Bogu, co Marceli traktował jako popadanie w tryteizm. Według niego w Bogu może być tylko jedna hipostaza, istota i osoba ${ }^{9}$. Drugim, istotnym rysem teologii Marcelego, zresztą również charakterystycznym dla tradycji antiocheńskiej, jest, jak on to nazywa, postulat wierności Biblii ${ }^{10}$, czyli przywiązanie do egzegezy literalnej i opozycja wobec alegorii.

1. Stworzenie - wcielenie. Teologia wcielenia jest u Marcelego ściśle powiązana z doktryną trynitarną, która jest też w pewnym sensie „historią Boga”. Oto jak wyglądają jej główne etapy:

Logos przed stworzeniem świata spoczywał w Bogu, jako będący w możności (dynamei). Bóg powziął zamiar stworzenia świata, co jest równoznaczne z faktem, że stan Logosu ulega zmianie. Oto jak Marceli opisuje najpierw stan Logosu przed powzięciem przez Boga zamiaru stworzenia, a potem zmianę stanu Logosu:

Frag. 59. Bóg bowiem nie potrzebował żadnego innego środka, żadnej materii, nic ludzkiego przy stwarzaniu, lecz jedynie tej zdolności, jaka była w jego własnej mocy. Bez swojego Logosu i mądrości Logosu nie mógłby Bóg rozmyślać nad stworzeniem nieba. Dlatego słusznie mówi: „Gdy niebo stwarzał byłam z Nim" $(\operatorname{Prz} 8,27)^{11}$.

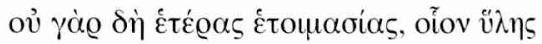

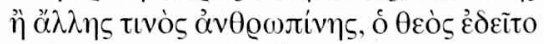

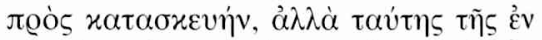

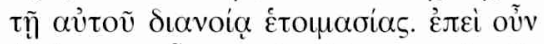

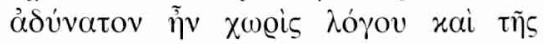

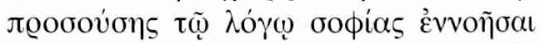

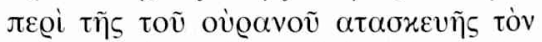

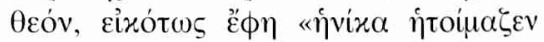

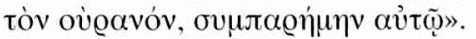

${ }^{6}$ Por. De sancta Ecclesia (CPG 2802), ,Studi e Testi” 5(1905) 87-98; M. Richard, Un opuscule méconnu de Marcel d'Ancyre, MSR 6(1949) 5-28.

7 Por. frag. 128.

${ }^{8}$ Polemikę z Marcelim spotykamy m.in. w pismach Cyryla Jerozolimskiego, Grzegorza z Nyssy, Bazylego Wielkiego i w pseudoatanazjańskiej IV Mowie przeciw arianom.

9 Por. frag. 76-78, 82 .

${ }^{10}$ Por. frag. 121.

11 Frag. 59, GCS 14, 195-196. 
Frag. 60. Zanim świat został stworzony, Logos był w Ojcu. Gdy zaś wszechwładny Bóg zamierzył stworzyć wszystko na niebie i na ziemi, potrzebował do stworzenia świata czynnej energii, dlatego właśnie, jako że nie było nic innego oprócz Boga (wyznajemy bowiem, że wszystko przez Niego się stało), Logos wyszedł z Niego stając się uczynicielem świata, tak jak on sam to wcześniej jako ideę wytworzył. Poucza nas o tym prorok Salomon mówiąc: „Kiedy stwarzał niebiosa, byłam z nim" i ,gdy stwarzał niewyczerpane źródła pod niebiosami, kiedy zakładał niewzruszone fundamenty ziemi, wraz z Nim działałam, ze mnie się radował" (Prz 8, 2730): radował się bowiem Ojciec, mogąc wszystko czynić swoją mądrością i mocą swojego Logosu ${ }^{12}$.

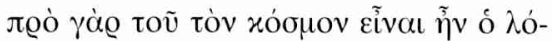

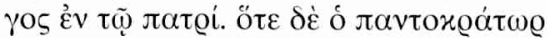

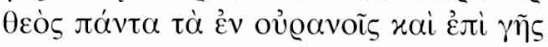

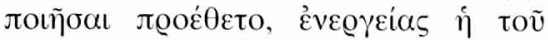

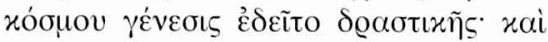

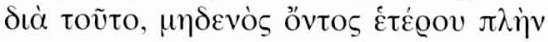

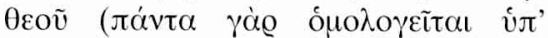

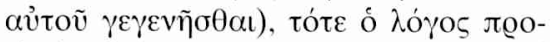

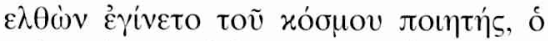

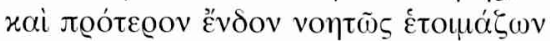

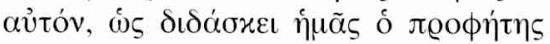

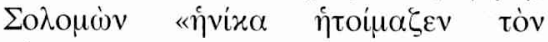

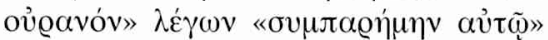

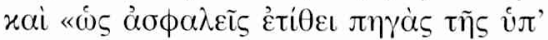

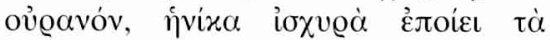

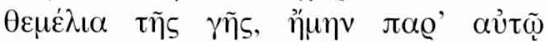

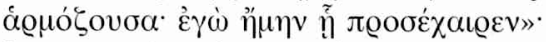

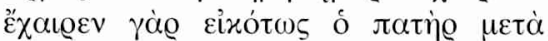

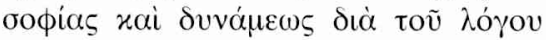

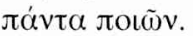

Logos więc uaktywnia się $\mathrm{w}$ dziele stworzenia i staje się energią (energeia $)^{13}$. Ten proces Marceli określa jako ,wychodzenie” (proerchomai) Logosu z monady ${ }^{14}$.

Aby opisać różnicę między stanem Logosu przed i po powzięciu zamiaru stworzenia świata przez Boga, Marceli interpretuje początek Ewangelii wg św. Jana:

Frag. 52. Poprzez wyrażenie ,na początku było Słowo" chce pokazać, że Logos był mocą w Ojcu. (Początkiem bowiem wszystkiego co zaistniało jest Bóg, ,z którego jest wszystko” (por. 1 Kor 8,6 ). Natomiast przez wyrażenie ,,a Słowo było u Boga" [chce pokazać że] Logos był energią u Boga (wszystko bowiem stało się przez Niego a nic nie stało się bez Niego). Wyrażenie zaś - ,a Słowo było Bogiem" pokazuje, że w boskości nie ma żadnego rozdarcia, gdyż

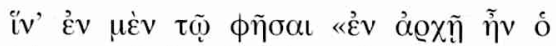

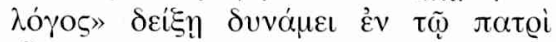

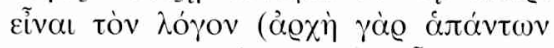

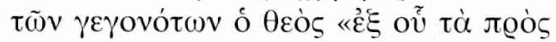

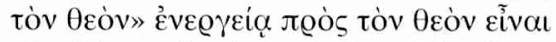

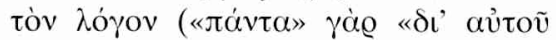

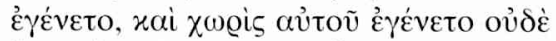

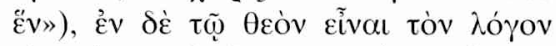

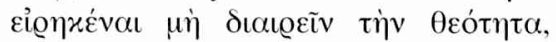

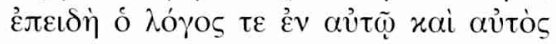

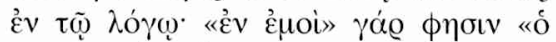

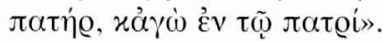

\footnotetext{
${ }^{12}$ Frag. 60, GCS 14, 196.

13 Por. frag. 52, 59-60, 67, 103.

14 Por. frag. 121.
} 
Logos jest w Nim samym i On sam w Logosie: mówi bowiem „we mnie jest $\mathrm{Oj}$ ciec i Ja jestem w Ojcu" $(\mathrm{J} 10,38)^{15}$.

Widzimy więc, że słowa „w Bogu” Marceli interpretuje jako stan Logosu dynamis, natomiast słowa „u Boga” jako energeia. Przy czym trzeba zauważyć, że przejście od stanu „w” do stanu „u” nie jest jeszcze rozszerzeniem się monady w triadę. Rozszerzenie się monady w triadę Marceli wiąże dopiero $\mathrm{z}$ drugim istotnym momentem historii ${ }^{16}$.

Marceli nigdy nie określa procesu ,wychodzenia” Logosu w zamiarze stworzenia jako zrodzenia. Terminu ,zrodzenie” używa Marceli wyłącznie dla określenia momentu wcielenia i to tylko mówiąc o zrodzeniu Syna, natomiast nie odnosi go nigdy do Logosu ${ }^{17}$ :

Frag. 33. Również święty Jan, apostoł i uczeń Pana, wspominając Jego wieczność, stał się prawdziwym świadkiem Logosu, gdy pisał: „Na początku był Logos, a Logos był u Boga i Bogiem był Logos" ( $(\mathrm{J} 1,1)$. Nie ma tam nic o zrodzeniu Logosu, natomiast trzykrotnie zaświadczone jest, że Logos był na początku ${ }^{18}$.

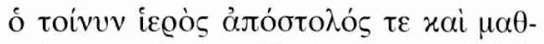

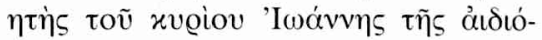

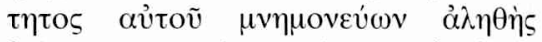

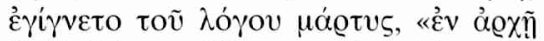

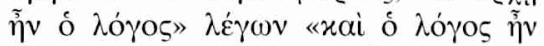

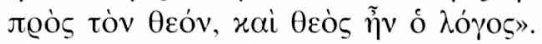

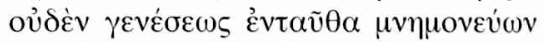

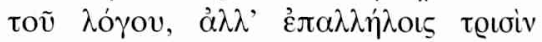

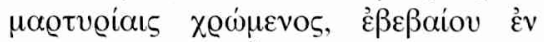

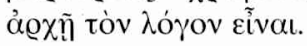

Podobnie jak Marceli nie mówi o zrodzeniu Logosu w odniesieniu do pochodzenia Logosu z Boga, tak samo, jeżeli chodzi o okres przed wcieleniem Marceli uważa, że jedynym dopuszczalnym określeniem jest „Logos” i wyraźnie podkreśla, że wszystkie pozostałe określenia, z określeniem „Syn” na czele, przysługują Logosowi dopiero po wcieleniu ${ }^{19}$.

Frag. 49. Nie bez powodu zatem, zanim zstąpił, był, jak to często mówiliśmy, Logosem. Po swoim zaś zstąpieniu na ziemię i przybraniu ciała otrzymał różne imiona, albowiem „Słowo stało się ciałem" $(\mathrm{J} 1,14)^{20}$.

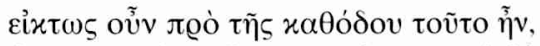

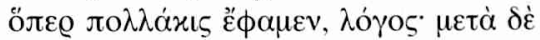

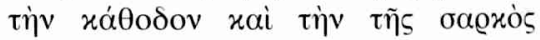

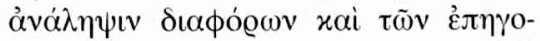

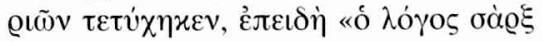

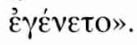

\footnotetext{
15 Frag. 52, GCS 14, 194.

16 Por. frag. 67, zob. niżej n. 24.

17 Por. frag. 32-33, 48-49.

18 Frag. 33, GCS 14, 190.

19 Por. frag. 43, zob. nizej n. 33.

20 Frag. 49, GCS 14, 193.
} 
Tak więc zamiar stworzenia świata, jaki powstaje w umyśle Boga, oraz fakt tego stworzenia są przez Marcelego opisywane jako zmiany w Bogu. Przez analogię do procesu formułowania myśli i następnie ich wypowiadania Marceli usiłuje opisać proces stwarzania świata przez Boga jako proces przechodzenia Logosu ze stanu „w Bogu” do stanu „u Boga”, od dynamis do energeia. Czy Marceli mówi tutaj o procesie, który dokonuje się w czasie? Raczej tak, gdyż w swoich tekstach używa określenia ,zanim” (pro $)^{21}$.

A zatem myśl Marcelego jest właściwie odwrotnością tego, co znajdujemy w teologii nicejskiej: teologia nicejska wyraźnie podkreśla, że przedwieczne zrodzenie Logosu nie dokonało się w czasie, a więc jest w niej pojęcie zrodzenia, a nie ma zależności czasowych, natomiast u Marcelego mamy do czynienia z myślą dokładnie odwrotną: tu nie ma pojęcia zrodzenia, a jest jakiś proces w czasie.

2. Moment wcielenia. Moment wcielenia jest drugim istotnym w ekonomii Bożej. I dopiero od momentu wcielenia Marceli używa wobec Logosu określenia „Syn”. Wcześniej Logos jest tylko Logosem. Oto jak opisuje moment wcielenia:

Frag. 67. Jeżeli więc Logos z samego Ojca wyszedł i do nas przybył, tak samo Duch Święty, jak to również Asteriusz wyznaje, pochodzi z $\mathrm{Ojca}^{22}$, i skoro sam Zbawiciel powiedział o Duchu: „Nie będzie mówił od siebie, ale powie to, co usłyszał, i przekaże nam to, co ma nastąpić. On mnie uwielbi, gdyż z mojego weźmie i wam przekaże". (J 16, 13.14). Czyż więc nie jest tu przedstawiona jasno i wyraźnie, choć nie w bezpośrednich słowach, monada? Rozszerza się ona w triadę, ale nie pozwala się rozerwać. Skoro bowiem Logos pochodzi od Ojca, również i Duch, jak to wyznajemy, od Ojca pochodzi, i skoro sam Zbawiciel o Duchu mówi: „Z mojego weźmie i nam przekaże", to czyż nie jest tu odsłaniana wcześniej zasłonięta tajemnica? Jak to by mogło być, że monada

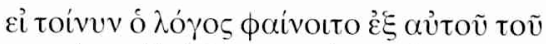

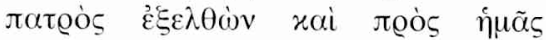

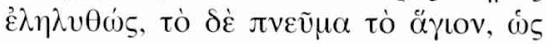

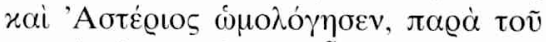

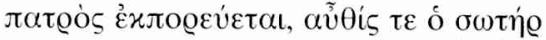

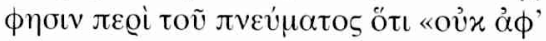

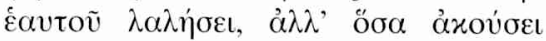

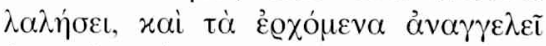

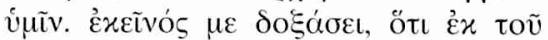

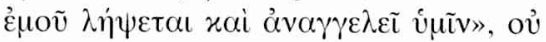

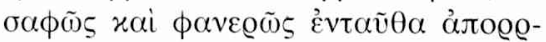

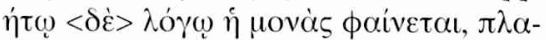

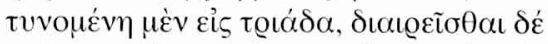

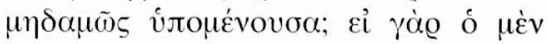

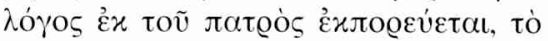

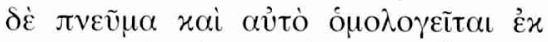

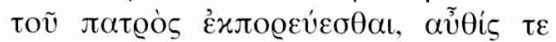

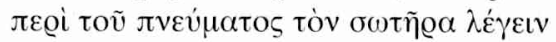

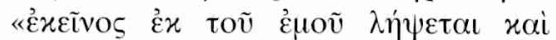

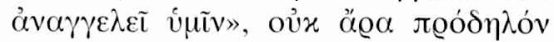

${ }^{21}$ Por. frag. 60, zob. wyżej n. 12.

22 Por. Asterius, frag. 59, ed. M. Vinzent: Asterius von Kappadokien. Die theologische Fragmente. Einleitung, kritischer Text, Übersetzung und Kommentar, Leiden 1993, 120. 
pozostanie nierozdarta, gdyby nie było tak, że rozszerzyła się w triadę; Jakżeby inaczej można było mówić o Duchu, że z Ojca pochodzi a potem znowu, że ,z mojego weźmie i da wam" (J 16, 13.14), a potem znowu, że tchnął na swoich uczniów mówiąc, ,,weźmijcie Ducha Świętego (J 20,22). Jak to więc jest, że z Ojca pochodzi, a od Syna, według tego nauczania, potrzebuje posługi? Albowiem, skoro są dwie oddzielne osoby, jak to naucza Asteriusz ${ }^{23}$, to albo Duch od Ojca pochodzi i nie potrzebuje On przyjąć pomocy od Syna (wszystko bowiem, co od Ojca pochodzi musi być doskonałe, i nie potrzebuje w żadnym razie pomocy od nikogo innego), albo też nie pochodzi on od Ojca, skoro otrzymuje łaskę od Syna i w Jego mocy ją przekazuje ${ }^{24}$.

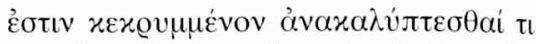

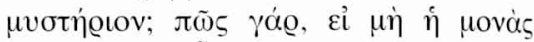

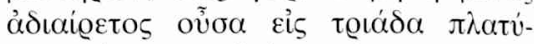

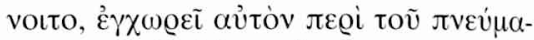

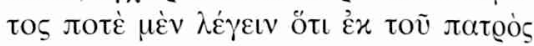

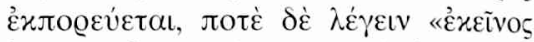

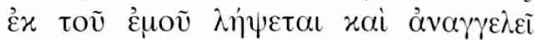

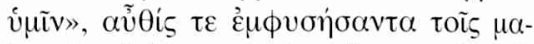

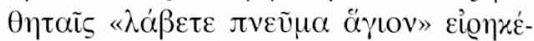

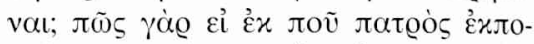

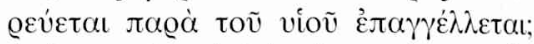

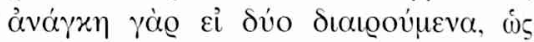

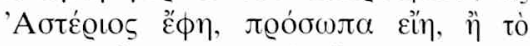

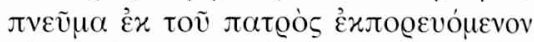

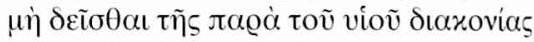

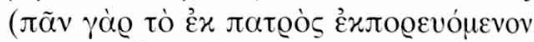

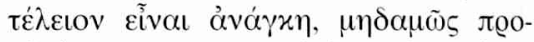

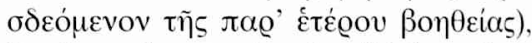

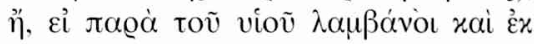

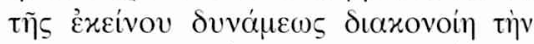

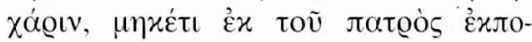

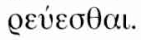

Moment wcielenia jest tu określony jako exerchomai - wyjście Logosu, ale tez jako „rozszerzenie się” Boga - monady w triadę: Logos „wychodzi” od Ojca, a Duch ,pochodzi” od Logosu. Jest to określenie podobne, choć nieco inne niż to, jakiego Marceli używa na pierwsze „wyjście” Logosu - ten proces Marceli określa jako „wychodzenie” (proerchomai) Logosu z monady ${ }^{25}$. A więc jest analogia pomiędzy wyjściem Logosu w dziele stworzenia a wyjściem Logosu we wcieleniu: proerchomai - exerchomai (wyjść do przodu - wyjść na zewnątrz). Ale trzeba także zauważyć, że Marceli tylko raz mówi o „wyjściu” Logosu. Zaraz potem w powyżej cytowanym fragmencie zaczyna używać pojęcia ekporeuo (pochodzić).

Moment wcielenia jest również momentem „rozszerzenia się” (platynomene, platynesthai) monady. Od tej chwili monada staje się diadą, a potem, wraz z wylaniem Ducha na Apostołów, triadą ${ }^{26}$. Oczywiście cel wcielenia jest soteriologiczny. Tu Marceli kontynuuje klasyczną i powszechną refleksję nad celem wcielenia (,Jezus przybył dla naszego zbawienia”), gdy pisze:

${ }^{23}$ Por. Asterius frag. 56, ed. Vinzent s. 118.

${ }^{24}$ Frag. 67, GCS 14, 197-198.

25 Por. frag. 121, GCS 14, 211-212. Niestety nie udało mi się znaleźć dwóch odrębnych polskich słów dla odróżnienia w tłumaczeniu tych dwóch greckich pojęć.

${ }^{26}$ Por. frag. 67-68, 71. 
Frag. 117. Logos nie przyjął naszego ciała po to, by mieć $\mathrm{z}$ tego jakąkolwiek korzyść, ale by ciało poprzez to zjednoczenie $\mathrm{z}$ Logosem osiągnęło nieśmiertelność... ${ }^{27}$.

Frag. 119. Nie ze względu na siebie samego, ale ze względu na nas przyjął ludzkie ciało. Skoro więc oczywistym jest, że przyjął je ze względu na nas, to wszystko to, co czyni dla nas swoją mądrością i mocą, dobiegnie końca w czasie sądu. To częściowe panowanie nie będzie bowiem potem potrzebne ${ }^{28}$.

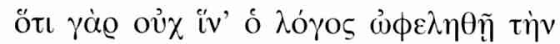

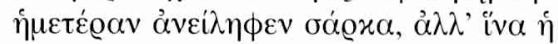

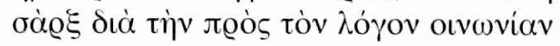
$\alpha \theta \theta v \alpha \sigma i \alpha \varsigma$ túx!...

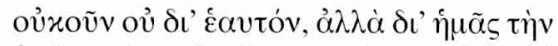

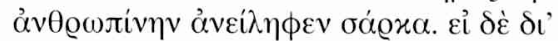

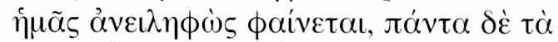

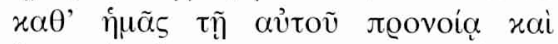

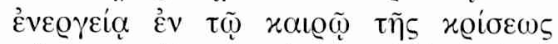

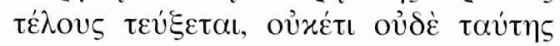

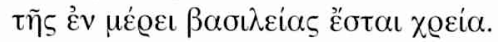

Wcielenie Logosu ma więc za cel ofiarowanie „ciału” nieśmiertelności. Marceli powtarza tu podstawową prawdę wiary chrześcijańskiej. Ale jak zobaczymy, ta soteriologia nie przekłada się na głębszą refleksję Marcelego nad sensem zbawienia ciała.

3. Chrystologia Marcelego. Powyżej zacytowane fragmenty wskazują, że podczas wcielenia dokonują się dwa procesy. Pierwszy proces - to opisane wcześniej „wyjście” od Ojca, a więc kolejna zmiana statusu Logosu wobec Boga. Drugi akt to ,przyjęcie ludzkiego ciała”. To ostatnie sformułowanie ${ }^{29}$ sugeruje chrystologię typu Logos - sarx, w sumie obcą duchowi teologii antiocheńskiej. Oto Logos „wychodzi od Ojca” i przybiera ludzkie ciało. Takie przedstawienie sprawy sugeruje, że w tym ciele to właśnie Logos jest podmiotem ziemskich działań Jezusa Chrystusa. Natomiast poniższe teksty, zwłaszcza pierwszy, wskazują już na typowo antiocheńskie podejście do postaci Jezusa:

Frag. 70. My zaś wiemy, że cielesna ekonomia odnosi się do człowieka, i wierzymy również, że według ducha pozostaje On nieprzerwanie zjednoczony z Ojcem ${ }^{30}$.

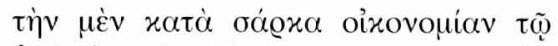

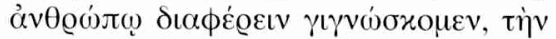

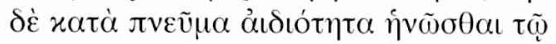

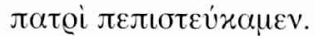

\footnotetext{
27 Frag. 117, GCS 14, 210.

28 Frag. 119, GCS 14, 211.

29 Por. frag. 117 i 119, zob. wyżej n. 27 i 28.

${ }^{30}$ Frag. 70, GCS 14, 198.
} 
Frag. 71. Jeżeli bowiem zastanowić się nad samym duchem, okazałoby się najprawdopodobniej, że Logos jest jednym i tym samym z Bogiem; skoro zaś zastanawiamy się, uwzględniając także ciało, jakie przybrał Zbawiciel, przedstawia się nam boża energia rozszerzona (na to ciało), ale tak, że monada najwyraźniej pozostaje nierozdzielona ${ }^{31}$.

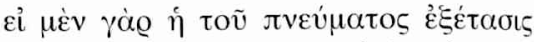

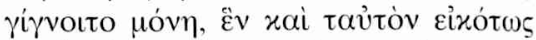

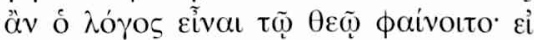

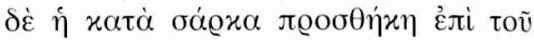

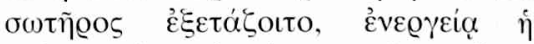

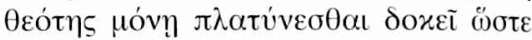

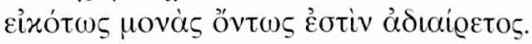

Logos więc „wychodzi” od Ojca, ale mimo to pozostaje w nim w głębokiej jedności. Natomiast „cielesna ekonomia”, czyli to, co dzieje się na ziemi podczas wcielenia, dotyczy „człowieka”. W momencie wcielenia mamy zatem $\mathrm{z}$ jednej strony zmianę stanu w samym Bogu, $\mathrm{z}$ drugiej jednak Logos pozostaje w głębokiej jedności z Bogiem. Takie przedstawienie sytuacji sprawia, że Marceli dość słabo potrafi opisać jedność Logosu i ciała w Jezusie Chrystusie. Mówi więc z jednej strony o ,przyjęciu ciała”, z drugiej zaś o „człowieku”, do którego odnosi się cielesna ekonomia. Przytoczone teksty nie dają jeszcze jasności odnośnie do tego, jak Marceli pojmuje człowieczeństwo Jezusa. W kolejnych fragmentach, jak się wydaje, mówi na ten temat nieco więcej. Oto jak przedstawia Jezusa, Logos wcielony:

Frag. 41. Dlatego też nie nazywa Go Synem Boga, ale wszędzie nazywa Go Synem Człowieka, aby poprzez takie wyznanie, przygotować człowieka, by dzięki wspólnocie z Nim był gotowy stać się synem bożym i, gdy wszystko zostanie wypełnione, ponownie, jako Logos, zjednoczyć się z Bogiem i tak wypełnić słowa Apostoła: wtedy zostanie on poddany Temu, który poddał mu wszystko i Bóg będzie wszystkim we wszystkim (1 Kor 15, 28). On będzie zatem tym samym, kim był na początku ${ }^{32}$.

Frg. 43. A zatem, z której strony by nie spojrzeć, jasno widać, że wiecznemu Logosowi nie było nadane żadne inne

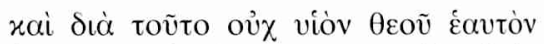

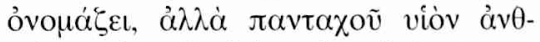

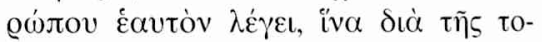

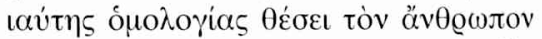

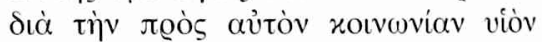

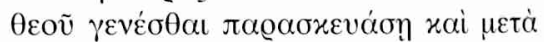

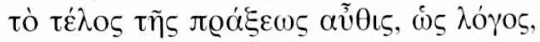

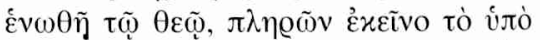

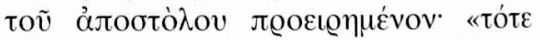

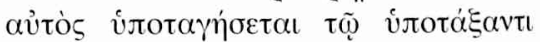

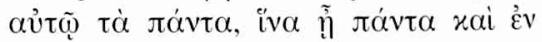

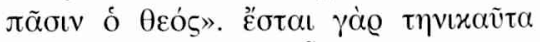

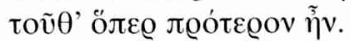

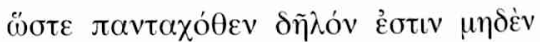

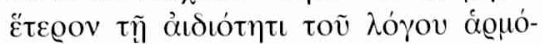

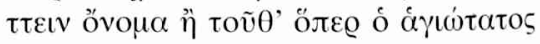

31 Frag. 71, GCS 14, 198.

${ }^{32}$ Frag. 41, GCS 14, 192. 
imię, jak tylko to, którego użył na początku swojej Ewangelii umiłowany uczeń Pana i Apostoł - Jan. Natomiast po tym, gdy przyjął ciało, często jest nazywany Chrystusem, Jezusem, Życiem, Drogą, Dniem, Zmartwychwstaniem, Drzwiami, Chlebem, czy jeszcze inaczej, jak to można w Piśmie Świętym znaleźć. Nie powinniśmy jednak przeoczyć Jego pierwszego imienia - Logos. Dlatego właśnie najświętszy Ewangelista i uczeń Pana, potężnie przez Ducha pobudzony, myślał o najpierwszym początku i o niczym późniejszym, pisząc: „Na początku było Słowo, a Słowo było u Boga i Bogiem było Słowo" (J 1, 1). Chciał bowiem w ten sposób pokazać, że nawet jeżeli mamy jakiekolwiek inne i nowsze imiona, to przecież to imię istniało już przed nową, cielesną ekonomią ${ }^{33}$.

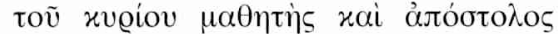

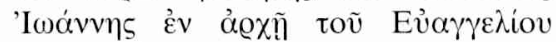

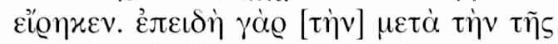

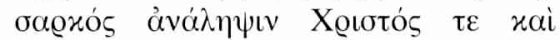

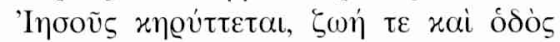
xai i

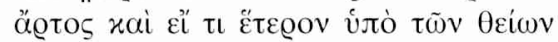

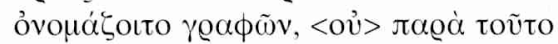

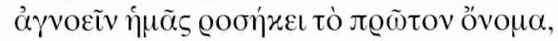

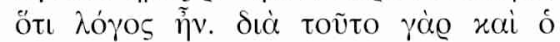

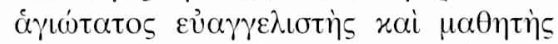

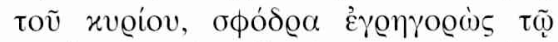

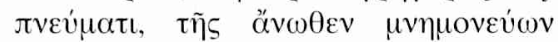

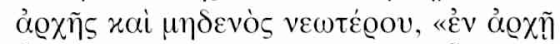

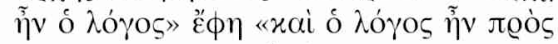

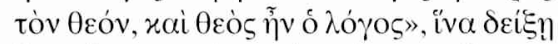

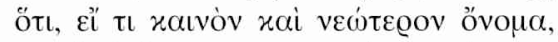

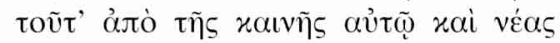

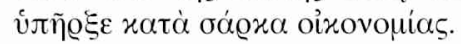

Jak widać, Marceli z jednej strony najczęściej mówi tylko o „,iele”, jakie przyjął Logos, a z drugiej o „synu człowieczym”, i podkreśla, że dopiero od momentu wcielenia Jezusowi przysługują kolejne imiona. To właśnie człowieczeństwo Jezusa jest widzialnym obrazem Boga niewidzialnego. Jak się wydaje, to człowiek jest podmiotem działań Jezusa. Także imiona, jakimi Pismo nazywa Jezusa: życie, droga, chleb, brama, Marceli odnosi raczej do człowieka, niż do Logosu.

Jednak Marceli popada w wewnętrzną sprzeczność, bo z jednej strony jego chrystologia jest dzieląca, a więc powinna podkreślać pełnię człowieczeństwa, $\mathrm{z}$ drugiej natomiast strony Marceli nie ma wiele do powiedzenia o człowieku Jezusie Chrystusie, a zwłaszcza ma kłopoty z przedstawieniem dalszego losu tego człowieka, o którym zresztą najczęściej mówi „ciało”. Powstaje więc pytanie o ciało Zbawiciela: czy będzie istniało jako samodzielny człowiek, tak jak pozostali zbawieni? Z logiki jego systemu teologicznego wynikałoby, że tak, ale Marceli w swoich tekstach nigdy o tym nie wspomina.

\section{Trwanie wcielenia - ciała Chrystusa po zmartwychwstaniu, wcielenie} a zmartwychwstanie ciał. Triada, jaką stał się Bóg po wcieleniu i zesłaniu Ducha, na końcu ekonomii powróci do pierwotnego stanu monady ${ }^{34}$. Marceli nie

\footnotetext{
33 Frag. 43, GCS 14, 192.

34 Por. frag. 117, 119, 121.
} 
bardzo potrafi wyjaśnić, co stanie się z człowiekiem, stworzeniem, a także z ciałem Jezusa Chrystusa na końcu ekonomii, gdy Logos powróci do monady. Logika jego systemu teologicznego nakazywałaby przyjąć, że wszelkie ciało zniknie, to jednakże jest sprzeczne z wypowiedziami biblijnymi i być może dlatego Marceli z jednej strony sugeruje to właśnie rozwiązanie, z drugiej zaś wyznaje, że tego nie wie. Niżej zostały przytoczone teksty, w których Marceli wykazuje, że czym innym jest nieśmiertelność, a czym innym „bycie godnym Boga”:

Frag. 118. Odnośnie zaś do ludzkiego ciała, wskazał na nie patrzącym i zapytał: „to was gorszy? A skoro ujrzycie Syna Człowieczego wstępującego tam, gdzie był przedtem? Duch ożywia, ciało na nic się nie przyda". (J 6, 61-63) $)^{35}$.

Frag. 119. Nie ze względu na siebie samego, ale ze względu na nas przyjął ludzkie ciało. Skoro więc oczywistym jest, że przyjął je ze względu na nas, to wszystko to, co czyni dla nas swoją mądrością i mocą, dobiegnie końca w czasie sądu. To częściowe panowanie nie będzie bowiem potem potrzebne $\mathrm{e}^{36}$.

Frg. 120. Jeżeli zaś ktoś mniema, że ciało ludzkie stało się godne Logosu gdyż dzięki zmartwychwstaniu uczynił je nieśmiertelnym, niech wie, że nie wszystko, co jest nieśmiertelne, jest godne Boga. Bóg bowiem jest większy niż nieśmiertelność, może przecież swoją wolą to, co nie istnieje uczynić nieśmiertelnym. A to, że nie wszystko, co nieśmiertelne godne jest zjednoczenia z Bogiem, pokazują Moce i Władze i Aniołowie, którzy, choć nieśmiertelni, nie posiadają jedności z Bogiem ${ }^{37}$.

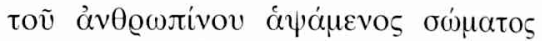

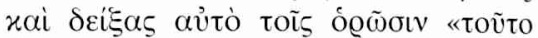

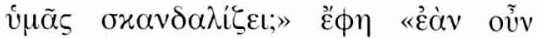

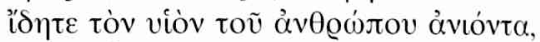

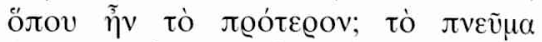

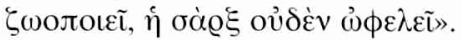

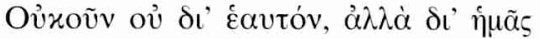

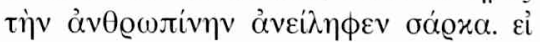

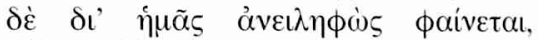

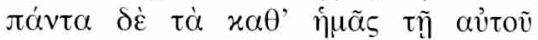

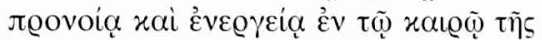

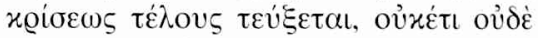

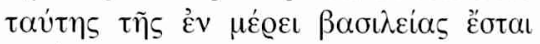

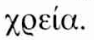

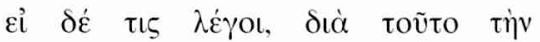

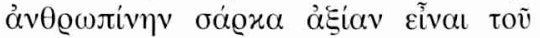

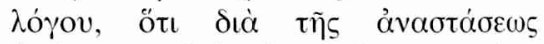

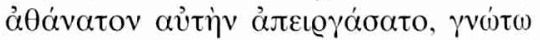

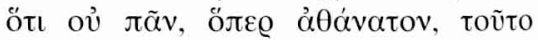

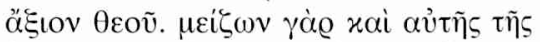

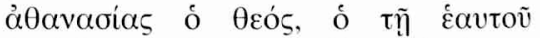

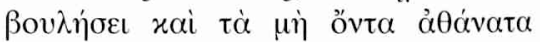

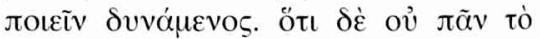

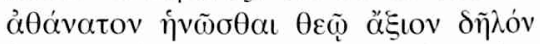

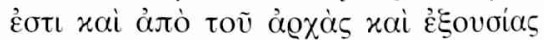

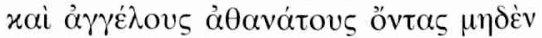

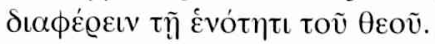

\footnotetext{
35 Por. frag. 118, GCS 14, 211.

36 Frag. 119, GCS 14, 211.

37 Frag. 120, GCS 14, 211.
} 
Zwłaszcza ostatni z przytoczonych tekstów wskazuje na to, że Marceli wyraźnie rozdziela pojęcia nieśmiertelności i zmartwychwstania ciała (to są jasno wypowiedziane prawdy biblijne) od trwania wcielenia Logosu. Można przypuszczać, że dla zbawionej ludzkości Marceli przewiduje stan taki, jaki obecnie posiadają „Moce, Władze i Aniołowie” - nieśmiertelni, ale nie pozostający w jedności z Bogiem. Jeżeli Marceli chciałby pozostać wierny tej teorii, to nie znajduje dla ludzkiego ciała (człowieczeństwa) Logosu możliwości wiecznego istnienia w jedności z Logosem. Natomiast, ponieważ jednak nie podkreślał wystarczająco jednoznacznie integralności człowieczeństwa Jezusa, trudno mu także jasno powiedzieć, że człowiek Jezus będzie przebywał tam, gdzie i pozostali zbawieni.

Marceli jest świadomy sprzeczności, ku której zmierza jego system, dlatego staje się ostrożny:

Frag. 121. Jeżeli zaś ktoś pyta o to ciało, które w Logosie zostało uczynione nieśmiertelnym, cóż mu odpowiemy? Jesteśmy bowiem przekonani, że to niepewna rzecz, dogmatyzować na temat spraw, o których nic dokładnego nie dowiadujemy się z Pisma Świętego. Jaką mocą moglibyśmy robić coś takiego, by obalać dogmaty innych? Raczej odpowiemy tym, którzy chcą się od nas dokładnie o tym dowiedzieć, że postępując za świętym Apostołem, wiemy, że ukryte tajemnice winniśmy teraz tak widzieć, jak on mówi: „Teraz widzimy niewyraźnie, jakby w zwierciadle, wtedy zobaczymy twarzą w twarz. Teraz poznajemy częściowo, wtedy poznamy całkowicie i tak też będziemy poznani”. (1 Kor 13,12) A więc nie mogę niczego jasnego powiedzieć o owym boskim, z boskim Logosem zjednoczonym, ciele. Wierzę zaś Pismu Świętemu, że jest jeden Bóg, i Jego Logos z Ojca wyszedł, aby wszystko przez Niego się stało. Po czasie sądu zaś i naprawienia wszystkiego i zniszczenia wszystkiego, co się przeciwstawia, On sam zostanie poddany Temu, który Mu poddał wszystko, Bogu i Ojcu, aby znowu Logos był w Bogu, jak to było wcześniej, przed początkiem świata. Wcześniej bowiem nie istniało nic oprócz Boga. Ale skoro wszystko miało stać się przez Logos, wyszedł Logos, jako moc działająca, i był On Logosem Ojca ${ }^{38}$.

Nawet w tym tekście, wskazującym, że Marceli jest świadom rysującej się trudności, nie wyrzeka się on tezy o powrocie Logosu do pierwotnego stanu spoczywania w Bogu - monadzie, czyli do stanu, jaki istniał nie tylko przed wcieleniem, ale nawet przed stworzeniem świata. Powstrzymuje się tylko od wyrażania opinii o tym, co dzieje się z ciałem, ale nie stawia żadnej hipotezy, która przedstawiałaby pozytywne rozwiązanie sprzeczności, w jaką się uwikłał. Ta sprzeczność jest niemała, gdyż Marceli, jak widzieliśmy, wcale nie jest

${ }^{38}$ Frag. 121, GCS 14, 211-212. 
pewien integralności człowieczeństwa Jezusa, a więc nie może też powiedzieć, że po powrocie Logosu do Boga pozostanie człowiek, Jezus, który będzie dzielił los innych zbawionych.

Marceli uznaje wcielenie Jezusa za moment, podczas którego nie tylko Logos przyjmuje na siebie ciało ludzkie, ale także dokonuje się jakaś zmiana w samym Bogu. Ta zmiana to rozszerzenie się monady w triadę. Jest to już druga zmiana. Pierwsza dokonała się na początku dzieła stworzenia. Wtedy Logos przeszedł od stanu „w Bogu” do stanu „u Boga”. Marceli podkreśla, że ani w pierwszym, ani w drugim momencie nie może być mowy o zrodzeniu. Termin „zrodzenie” odnosi tylko do narodzenia Jezusa z Maryi. Zmiany, jakie zachodzą w Bogu, związane najpierw ze stworzeniem świata, a potem z wcieleniem, nie są trwałe, wręcz przeciwnie - są odwracalne i przejściowe. Po zakończeniu historii świata Bóg ponownie powróci do stanu monady. Równiez wcielenie się zakończy. Marceli przedstawia wcielenie jako coś dla Logosu raczej „zewnętrznego”, oraz jako coś tymczasowego. Po zakończeniu „ekonomii cielesnej" Logos ma powrócić do swojego pierwotnego stanu - spoczywania „w Bogu”.

Marceli nie potrafi przedstawić w konsekwentny sposób ostatecznego losu ciała Chrystusa. A więc choć uznaje, że Chrystus wcielił się dla zbawienia człowieka i ciała, oraz przyznaje, że wcielenie przyniosło ciału nieśmiertelność, nie potrafi szerzej opisać w ramach swojego systemu teologicznego, na czym ma polegać zbawienie ciała. Pisząc, że „nie wszystko, co nieśmiertelne, godne jest zjednoczenia z Bogiem” oraz że „nie mogę niczego jasnego powiedzieć o owym boskim, z boskim Logosem zjednoczonym, ciele" Marceli stwierdza, że nie potrafi w ramach swojego systemu teologicznego znaleźć ostatecznego miejsca dla ciała Jezusa. Jest to tym bardziej kłopotliwe, że Marceli niezbyt jasno mówi o pełnym człowieczeństwie Jezusa, a więc nie potrafi nawet powiedzieć, kim będzie ten, co pozostanie po powrocie Logosu do Boga. Poza tym Marceli właściwie przyznaje się, że nie potrafi niczego istotnego powiedzieć na temat zbawienia człowieka w ciele. Co najwyżej jest w stanie przyznać zbawionym status „Mocy i Władz i Aniołów, którzy, choć nieśmiertelni, nie posiadają jedności z Bogiem".

Jak się okazuje, choć na soborze w Nicei Marceli był jednym z gorliwszych zwolenników Aleksandra i Atanazego, w istotnych punktach jego teologia znacząco różniła się od teologii Atanazego: teologia nicejska wyraźnie podkreśla, że przedwieczne zrodzenie Logosu nie dokonało się w czasie, a więc jest w niej pojęcie zrodzenia, a nie ma zależności czasowych, natomiast u Marcelego mamy do czynienia z myślą dokładnie odwrotną: tu nie ma pojęcia zrodzenia, a jest jakiś proces trwający w czasie. 


\title{
THE INCARNATION IN MARCELLUS' OF ANCYRA THEOLOGY
}

\author{
(Summary)
}

Marcellus perceives the incarnation of Jesus as the moment when not only does the Logos assume a human body, but a change also occurs in God himself. The change consists in the expansion of a monad into a triad. It is the second transformation already. The first one took place at the beginning of creation. It was then that the Logos passed from the state of being ,in God" to being ,with God”. Marcellus underlines that neither the first nor the latter can be defined as generation. The term „generation refers only to Jesus' birth from Mary. The changes undergone by God, first at creation, then at the incarnation, are not of permanent nature. On the contrary, they are temporary and reversible. Upon completing the history of the world, God will return to the monadic state. The incarnation will also come to an end. Marcellus presents the incarnation as temporary and ,external” in relation to the Logos. When the "carnal economy" is completed, the Logos is to return to His original state of resting , in God”.

Marcellus was unable to give a coherent outline of the fate of the body of Christ. Even though he acknowledges that the incarnation resulted in the immortality of the body, his theological system does not include an explanation of what the salvation of the body means. Writing that ,all that is immortal is not worthy of being united with God”, and that „I cannot say anything specific about that divine Body which is united to the divine Logos", Marcellus admits that he is unable to finally place the Body of Jesus in his theological system. What is even more confusing, Marcellus is not very clear while discussing the humanity of Jesus, thus, he is not able to define the nature of the one to remain after the Logos returns to God.

What is more, Marcellus actually admits that he is unable to say anything relevant about the salvation of man in his body. He can merely grant the saved ones the status of „Principalities and Powers, and Angels, who, though immortal, are not one with God". Apparently, though Marcellus was one of the most ardent supporters of Alexander and Athanasius at the Council of Nicaea, his theology differs significantly from that of Athanasius in a number of important points. The theology of Nicaea stresses that the eternal generation of the Logos did not take place in time, thus, it contains the concept of birth, but no time references. On the contrary, the thought of Marcellus does not provide for the very concept of eternal generation, but for a process within a time frame. 